\title{
A CRITIQUE OF THE SUPPOSED RODENT ORIGIN OF HUMAN GIARDIASIS.*
}

BY CHARLES E. SIMON, B.A., M.D.

(Received for publication, April 20, 1922.)

Plate XVI.

INTRODUCTION.

In his publication of 1881 , Grassi expressed the opinion that human giardiasis might passibly be of rodent origin. He was led to this conclusion by the discovery that giardias oceur quite commonly in various representatives of the sub-family Murinae (Mus musculus, Mus decumanus, and Mus sylvaticus), as well as in the common meadow mouse, Arvicola arvalis, of the district of Italy (Lombardy) where he carried on his investigations, and that, owing to the habit of the peasants of keeping their bread in open garrets its contamination with the dung of some of these rodents was of common occurrence. Grassi's suggestion was, however, only a suggestion, and unsupported by any actual facts. It has nevertheless been handed down in the literature practically to the present day.

Inasmuch as human giardiasis is at times associated with chronic diarrhoea and is in the opinion of some observers its actual cause, it seemed of importance to ascertain the manner in which the infection is spread, and hence to investigate amongst the various possibilities also the validity of Grassi's hypothesis.

To this end, it became necessary to determine (1) whether the giardia which is found in man is morphologically identical with the form or forms which oecur in those rodents which might possibly enter into consideration, viz., the common house mouse, the Norway rat and certain types of meadow mice, viz., Arvicola in Europe and Microtus in North America; (2) to ascertain whether the various types of giardia are non-specific for their hosts, e.g., whether the human

* This is the second of a series of papers on the genus Giardia from the Department of Medical Zoology of the School of Hygiene and Public Health of the Johns Hopkins University. The first paper of the series was published in the American Journal of Hygiene, 1921, vol. I, pp. 440-482. 
form can live in the intestine of the rat, or the rat form in the intestine of the mouse; (3) if host specificity does not exist, whether a given type after transference from its usual host to a host of a different species retains its original morphological characteristies.

\section{Material AND Methods}

The writer's work is based upon the study of the following forms : (a) Trophozoites and cysts of the type of Giardia which is found in man, obtained from five different individuals. The results of the morphological and statistical study of this material have already been published under the title "Giardia enterica: A parasitic intestinal flagellate of man" (Simon 1921).

(b) Trophozoites and cysts of the type of Giardia which Kofoid and Christiansen found in Microtus californicus californicus (Peale), and which these writers have named Giardia microti (1915). I owe specimens from three different animals of this species to the courtesy of Dr. W. C. Boeck.

(c) Trophozoites and eysts of the type of Giardia which I found in Microtus pennsylvanicus acadicus. These animals were obtained at Chester, Nova Scotia. The organism in question is apparently identical with the Giardia microti of California. The statistical results of the study of this type are based upon specimens obtained from five different hosts, while the general morphological study of the organism has reference to specimens derived from 26 different hosts.

(d) Trophozoites and eysts of the type of Giardia which is commonly known as Giardia muris. Most of the material of this order was obtained from eulture rats and culture mice of the colony belonging to the Department of Medical Zoology. A few specimens the writer owes to the courtesy of Professor C. A. Kofoid. In this connection, it may be mentioned that an examination of some 30 wild rats and 18 wild mice, secured in Baltimore, showed that none of these animals harbored giardias. Two wild rats and four house mice which were caught near Chester, Nova Scotia, were likewise free.

(e) In the course of the present study, two culture rats were found to be infected with two types of Giardia. These will be considered in detail later on.

The material was examined partly in the living state, partly after 
fixation in Schaudinn's solution and after staining with Heidenhain's haemotoxylin, Giemsa's stain, and Mann's stain.

1. A comparison of the human type of Giardia with that FOUND IN CULTURE RATS AND CULTURE MICE.

At the time when Grassi made his discovery of the occurrence of giardia in Mus musculus, Mus decumanus, and Arvicola arvalis (1879), he was probably more interested in the general fact of the occurrence of parasites of this order in the animals mentioned, than in the question whether they beonged to the same species as those found in man. The problem of the identity of the human and the rat-mouse form was, as a matter of fact, not raised until 1908, when Benson published his well-known study on the structure and species of the genus Lamblia. In this study he pointed out what he considered as essential differences between the forms occurring in man, the mouse, and the rabbit and gave to the mouse form the name of Lamblia muris. From the context it is not altogether elear whether he studied this type in wild mice or in culture mice, though the latter is the more probable.

Admissibility of using culture rats for this investigation.-In. asmuch as Grassi found the parasite in question in wild rats and mice, it may be questioned whether any conclusions regarding morphological differences based upon the examination of "culture" material would be valid. The writer was particularly anxious to secure naturally infected wild rats and mice, but neither in Baltimore nor Nova Scotia could he find any but "clean" animals. But, as the culture rat is merely a, domesticated variety of the Norway rat (Mus decumanus), and the culture mouse of the common house mouse (Mus musculus), the conclusion seemed justifiable that the type of giardia which is so common in these domesticated strains would be the same as that found in the wild forms or at least that the type occurring in the wild strains could maintain itself in the domesticated strains. As a matter of fact no descriptions of the type found in the wild mouse and rat exist. The probable correctness of the conclusion that the forms are identical is supported by the writer's findings, that $M$ us decumanus can be infected readily with the common giardia of culture mice and culture rats and that no morphological differences develop in the new host (see below).

Necessity of establishing standards for purposes of comparison.In my paper on the type of giardia occurring in man (1921), I pointed 
out that for comparative studies it was essential to analyze the descriptions furnished by other investigators, and to attempt to harmonize any conflicting opinions that might have been expressed, so that a standard should become available for a discussion of questions of specificity. The same will be necessary in connection with the animal forms under consideration.

Number of blepharoplasts and axostyles.-The first adequate description of the mouse type was furnished by Wenyon (1907). His studies were based on material obtained from (presumably) culture mice of the Pasteur Institute of Paris and of the Zoological Institute of Munich. His conception of the structure of the organism can be seen at a glance by referring to Plate XVI, Fig. 1. In 1908 came Bensen's description of the organism (Plate XVI, Fig. 2), and in 1915 that of Kofoid and Christiansen (1915b) (Plate XVI, Fig. 3). A study of these deseriptions shows the following points on which the writers are not in aceord. Both Wenyon and Bensen describe and picture the presence of a pair of granules (blepharoplasts) lying between the two nuclei and a little anterior to the anterior poles of the latter, from which the antero- and postero-lateral flagella originate, and between these of two additional structures, granule-like according to Bensen and rod-like according to Wenyon, from which two axostyles originate and become continuous with the two caudal flagella. But, while Wenyon saw no communicating fibril uniting the outer set of granules to the corresponding nuclei, Bensen pictures a distinct rhizoplast running from each granule to a granule in the anterior border of the corresponding nuclear membrane.

Kofoid and Christiansen in their description of the mouse form state $(1915$, p. 35) that they found two large, spheroidal blepharoplasts, "symmetrically placed at the right and left sides of the anterior end of the axostyle" (which latter they conceive to be single in the resting stage of the animal), " joined by a slender, deeply staining transverse fibre or commissure. ..." They further state that each karyosome is connected with the corresponding blepharoplast by means of a rhizoplast, with the interposition of an "anterior membrane granule." In other words Kofoid and Christiansen do not recognize the existence of the four granules of Wenyon and Bensen, in the resting stage of the animal.

My own findings are in the main in accord with those of Kofoid and Christiansen but $I$ do not recognize the existence of a single 
axostyle.* The question then arises how to account for the four granules of Wenyon and Bensen. It is possible that these writers encountered forms in which binary division had begun and in which four blepharoplasts actually were present, and that they regarded this as the normal condition. In such an event the writers should theoretically have seen not only the two axostyles which are present in the quiescent stage, but also the beginnings of the second set of axostyles. But it must be borne in mind that at that stage in the development of our knowledge of the structure of these organisms these very fine points may well have been overlooked, and that in the mouse form these details are particularly hard to make out. In my human material I have found forms with dividing blepharoplasts only on rare occasions, while in some of my animal material they were not so uncommon, and in Dr. Hegner's preparations of the dog and rabbit form (1922) they were more numerous than forms with a single pair only. We may conclude that the number of internuclear granules depends upon the stage of development of the organism, that two blepharoplasts only exist during the resting stage of the animal, while four may be encountered at a very early stage of division. The two blepharoplasts are united with each other and with the karyosomes of the corresponding nuclei by an exceedingly fine fibril which in the mouse form can be seen only in exceptionally favorably differentiated specimens. It is in the writer's experience more common in the mouse form to find the terminal portions of the axostyles attenuated rather than clubbed, and apparently not united either with each other or the nuclei (Text figure 3 ).

Having come to the above conclusion regarding the number of blepharoplasts and their connecting fibrils we cannot agree with Bensen that the mouse form can be distinguished from the human type on the basis of the presence in the latter of a fibril uniting the karyosomes to the blepharoplasts and these to each other.

Basal granules.-Bensen has pictured the presence of a basal gran-

* In their recent publication on Giardia enterica Kofoid and Swezey (1921) state that this form has two axostyles. It is gratifying to the writer to note that Kofoid and Swezey are in agreement with the position of the writer and all other observers on this point. Inasmuch as they had previously insisted that in the giardia of the culture mouse and the California meadow mouse the axostyle is a single organ, we are probably justified in inferring that they have abandoned this idea, and in their table of comparison between rodent forms and the human form they do not refer to such differences, which they no doubt would have done, if they still believed in the single axostyle. 
ORIGIN OF HUMAN GIARDIASIS.

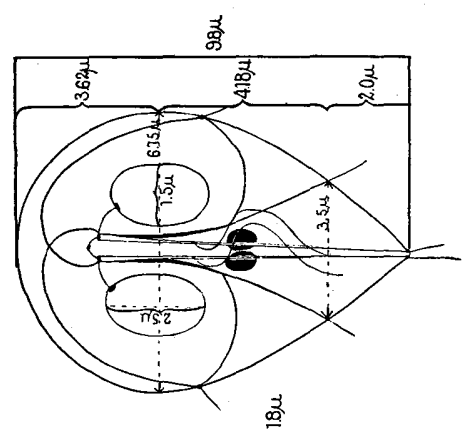

芯弯安

영

突它

is 0 월

死

영

魚

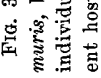

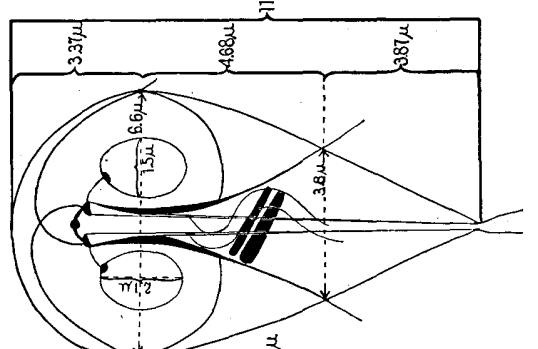

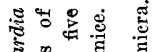

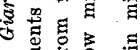

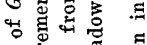

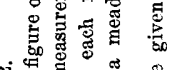

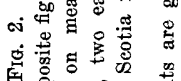

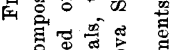

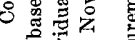

क. .

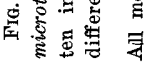

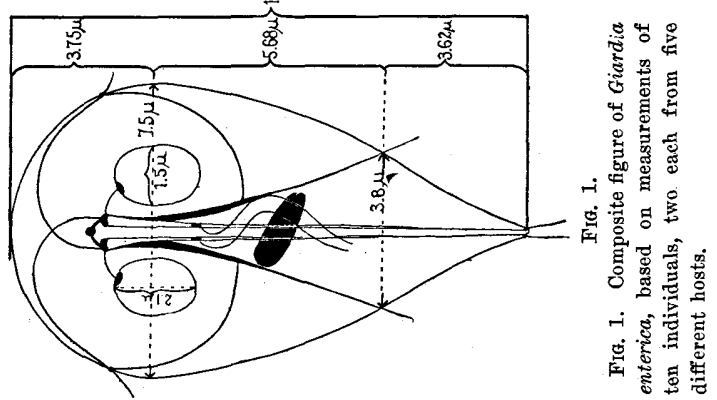


ule at the points of exit from the body of the parasite of the anterolateral and caudal flagella, both in the mouse form and the human Iorm, also at the points of exit of the postero-laterals in the mouse form, but not in the human form. Wenyon makes no mention of basal granules of this order in his description of the mouse form, while Kofoid and Christiansen state that there is such a granule where the antero-laterals emerge, none as a rule at the points of exit of the postero-laterals, "though in some individuals a small one is present." Where the caudals leave the body Kofoid and Christiansen state "there may be a basal granule, but this is not always present." "After the division of the single axostyle to form two, one flagellum and one basal granule go with each daughter axostyle." This view the writers no doubt have abandoned. In their paper on Giardia enterica Kofoid and Swezey state that there is no distinct basal granule at or near the point of emergence of either the antero-lateral, the postero-lateral or the caudal flagella in that parasite. This is erroneous so far as the postero-lateral and caudal flagella are concerned, each of which starts from a basal granule. The mouse-rat form cannot be differentiated from the human form, however, on the basis of the presence or absence of the granules, as they cannot be distinguished in all specimens. At the points of emergence of the postero-laterals I have not seen structures of this type in either form.

The "parabasal" bodies.-In discussing the essential points of differenee between the mouse form and the human form, Bensen lays a good deal of stress upon the character of the parabasal body (räthselhafte Körper) or bodies. He thus states that in the human form "the body in question is very large, located transversely, that it is thicker in the center but does not become much narrower towards its rounded ends." Bensen evidently regards it, as also that of the mouse form, as a single organelle. The mouse form he describes as of plump appearance, almost entirely round and not rarely surrounded by a halo (clear zone). Wenyon recognizes the presence of two very dark staining bodies of this order, one on each side of the middle line. Kofoid and Christiansen state that the mouse form is provided with a pair of "large, subellipsoidal, deeply staining masses, sometimes fused into one, lying dorsal to the middle of the axostyle."

My own observations on the mouse form agree with those of Wenyon and Kofoid and Christiansen, but I have not found the parabasal either uniformly present or of uniform size. In my human material I have rarely met with appearances which suggest the existence of two 
parabasal bodies and there also I have found this structure of inconstant occurrence. When present and fully developed it appeared club-shaped which feature might well serve to differentiate the corresponding organism from the mouse form, but unfortunately it is very frequently absent, or imperfectly developed.*

We may conclude then that with the exception of the parabasal body no essential structural differences exist between the mouse form and the human type and that apparent differences are merely the expression of stages in the life history or development of organisms.

Size and form.--If now we turn to the question of size and form we meet with differences which are quite striking. Bensen clearly recognized this. He described the human form as of slender outline, not much wider in the middle than in the anterior portion, while posteriorly the lines run almost straight to the tail. of the mouse form he says that this attains only three quarters of the size of the human form, that it has a short stocky shape and that the lines of the posterior portion, in converging toward the caudal extremity, are distinctly concave. He does not give any actual measurements, however. Inasmuch as several later observers (Noc 1909) state that size cannot serve as a criterion of differentiation, without, however, giving actual data, it seemed indicated to the writer that this factor should be studied in detail.

To this end 250 specimens of the mouse form, representing five different hosts, were measured in reference to length and breadth of body, from which the ratio $L / B$ was calculated. The minimum, maximum and mean values for each set of 50 are shown in Table I, as well as the composite values, with the probable error of the mean.

In the same table the corresponding values for the human form are given. In chart 1 will be found the frequency values for the two forms, as well as the type which occurs in the meadow mouse, the general morphological comparisons of which with the human form will be considered below.

A study of the tabulated values will show that there is a marked difference in the length of the two types of organisms. A comparison of the composite means shows a difference of 3.95 with a corre-

* In a recent case of human giardiasis which occurred under the observation of Dr. Walter Thomas of the Clifton Springs Sanitarium and in which living material was obtained direetly from the duodenum, the writer met with fairly numerous specimens in which two distinet parabasal bodies could be discerned. In fecal material such pictures are however very rare. 
TABLE I.

Measurements in micra of the trophozoites of Giardia muris and Giardia enterica.

These measurements have reference to the trophozoites from five different eases of infection, with Giardia muris and Giardia enterica, respectively.

\begin{tabular}{|c|c|c|c|c|c|c|c|c|c|c|}
\hline & \multirow{2}{*}{ 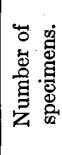 } & \multicolumn{3}{|c|}{ Length. } & \multicolumn{3}{|c|}{ Breadth. } & \multicolumn{3}{|c|}{$\begin{array}{l}\text { Ratio of length } \\
\text { to breadth. }\end{array}$} \\
\hline & & 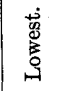 & 苞 & Mean. & 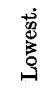 & 葛 & Mean. & 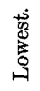 & 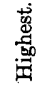 & Mean. \\
\hline 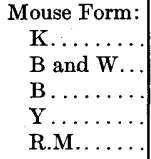 & $\begin{array}{l}50 \\
50 \\
50 \\
50 \\
50\end{array}$ & $\begin{array}{l}7.75 \\
8.25 \\
8.75 \\
8.25 \\
7.25\end{array}$ & $\begin{array}{l}12.25 \\
11.75 \\
12.75 \\
11.25 \\
11.25\end{array}$ & $\begin{array}{r}9.44 \\
10.36 \\
10.35 \\
9.83 \\
8.77\end{array}$ & $\begin{array}{l}5.25 \\
6.75 \\
6.75 \\
6.25 \\
5.25\end{array}$ & $\begin{array}{l}8.25 \\
8.75 \\
9.75 \\
8.75 \\
8.25\end{array}$ & $\begin{array}{l}6.82 \\
7.56 \\
8.08 \\
7.18 \\
6.67\end{array}$ & $\begin{array}{l}1.1 \\
1.1 \\
1.1 \\
1.1 \\
1.1\end{array}$ & $\begin{array}{l}1.7 \\
1.5 \\
1.4 \\
1.6 \\
1.6\end{array}$ & $\begin{array}{l}1.39 \\
1.38 \\
1.29 \\
1.37 \\
1.32\end{array}$ \\
\hline Composite.... & 250 & 7.25 & 12.75 & $\begin{array}{r}9.75 \ddagger \\
\pm 0.04\end{array}$ & 5.25 & 9.75 & $\begin{array}{r}7.26 \ddagger \\
\pm 0.04\end{array}$ & 1.1 & 1.7 & $\begin{array}{r}1.35 \ddagger \\
\pm 0.006\end{array}$ \\
\hline $\begin{array}{c}\text { Human Form: } \\
\text { Maryland I } \\
\text { Maryland } \\
\text { II. ....... } \\
\text { Maryland } \\
\text { III...... } \\
\text { South Caro- } \\
\text { lina..... } \\
\text { French.... }\end{array}$ & $\begin{array}{r}73 \\
118\end{array}$ & $\begin{array}{l}10.25 \\
11.25 \\
9.25\end{array}$ & $\begin{array}{l}17.25 \\
15.25\end{array}$ & $\begin{array}{c}14.11 \\
14.34 \\
11.61 \\
12.70 \\
14.28\end{array}$ & $\begin{array}{l}6.25 \\
6.25 \\
5.00\end{array}$ & $\mid \begin{array}{l}10.25 \\
9.25 \\
8.00\end{array}$ & $\begin{array}{l}7.83 \\
6.31\end{array}$ & $\begin{array}{l}1.5 \\
1.4 \\
1.4\end{array}$ & $\begin{array}{l}2.3 \\
\\
2.0 \\
\\
2.2 \\
2.3\end{array}$ & $\begin{array}{l}1.80 \\
1.80 \\
1.79 \\
1.80 \\
1.60\end{array}$ \\
\hline Composite.... & 338 & 9.25 & 20.25 & $\begin{array}{l}13.70 \ddagger \\
\pm 0.2\end{array}$ & 5.00 & 10.25 & $\begin{array}{r}7.46 \\
\pm 0.034\end{array}$ & 1.4 & 2.3 & $\begin{array}{r}1.84 \ddagger \\
\pm 0.009\end{array}$ \\
\hline $\begin{array}{c}\text { Differences be- } \\
\text { tween the } \\
\text { two forms. }\end{array}$ & & 0.00 & 7.50 & 3.95 & 0.25 & 0.50 & 0.20 & 0.3 & 0.6 & 0.49 \\
\hline
\end{tabular}

sponding probable error amounting to 0.3031. This of course is highly suggestive. But it might be argued that the two types of organisms might after all be the same, and that the difference in size is merely the expression of a difference in environment. This, how-

$\ddagger$ The composite means were obtained, not from the means of the five animals, but from the measurements of the total number. 
ever, is improbable. Differences in environment might possibly affect the mean length, but it would hardly bring about such a widely different type of distribution as we have in the present instance and as is shown in chart 1 .

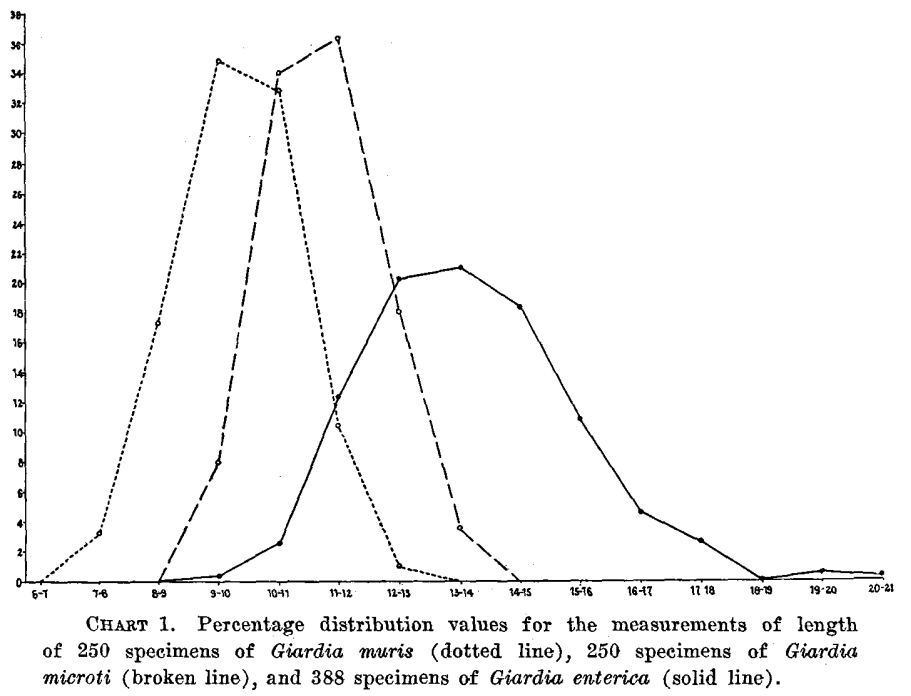

TABLE II.

Showing measurements of the mouse type found in a white mouse and in its sub. sequent host-a black and white rat.

\begin{tabular}{|c|c|c|c|c|c|c|c|c|c|}
\hline & \multicolumn{3}{|c|}{ Length of body. } & \multicolumn{3}{|c|}{ Breadth of body. } & \multicolumn{3}{|c|}{$\begin{array}{l}\text { Ratio of length } \\
\text { to breadth. }\end{array}$} \\
\hline & $\begin{array}{l}\dot{3} \\
\stackrel{0}{0} \\
\stackrel{8}{0}\end{array}$ & 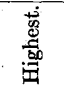 & 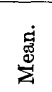 & 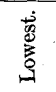 & 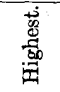 & 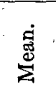 & $\begin{array}{l}\dot{+} \\
\stackrel{0}{0} \\
\stackrel{0}{0}\end{array}$ & $\begin{array}{l}\frac{1}{0} \\
\frac{0}{00} \\
\frac{0}{10}\end{array}$ & 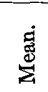 \\
\hline Mouse.... . & 8.25 & 11.25 & 9.83 & 6.25 & 8.75 & 7.18 & 1.1 & 1.6 & 1.37 \\
\hline Rat.... & 7.25 & 11.25 & 8.77 & 5.25 & 8.25 & 6.67 & 1.1 & 1.6 & 1.32 \\
\hline Differences.... & 1.00 & 0.00 & 1.06 & 1.00 & .0 .50 & 0.51 & 0.0 & 0.0 & 0.05 \\
\hline
\end{tabular}


The probable correctness of this view is strengthened by the fact that a transfer of a strain occurring in a white mouse to a white rat (by feeding) resulted in insignificant differences (Table II) only and hardly changed the curve of distribution at all (see chart 1) and last, but not least, we encountered a double infection in a culture rat, where an evident mouse form lived together with an entirely different type. The findings in this animal will be found tabulated in Table III and the length and length/breadth frequency distribution in charts 5 and 6 . The differences are so marked that they require no special comment.

\section{TABLE III}

Showing measurements which were obtained in a coinfection in a culture rat, one type being the common mouse-rat type, the other that which the writer has temporarily termed Giardia sp.

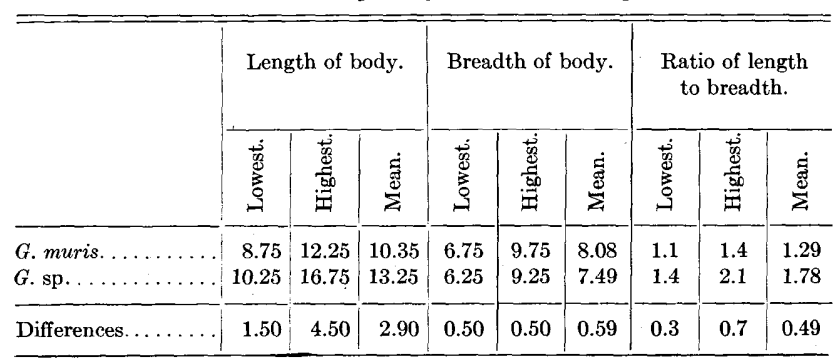

Of the origin of the large form in this case, I have no knowledge. The animal was a member of the rat colony of the Department of Medical Zoology and had not come in contact with other animals either directly or indirectly for a period of at least six months, so that we may assume that the two types of organisms lived side by side in the same animal for at least that length of time.

In going over Boeck's paper entitled "Studies on Giardia microti" (1919), I find that this investigator encountered a type of giardia in culture rats in Berkeley, California, which "resembled G. microti as far as the general form of the body and the organelles are concerned." It measured from 13 to $17 \mu$ in length and from 6 to 9 in width. I am inclined to think that we were both dealing with the same type, but I do not believe that we can regard this as Giardia microti in view of the fact that in my experience culture rats cannot be infected with that type (see experimental data below). 
In principle the observation of this coinfection is of course of the greatest importance and strongly supports the probability of the existence of different species.

A comparative study of the breadth values of the mouse and the human type (Table I and chart 2) does not reveal such clear-cut differences, either in the ranges or the means, nor in the type of distribution, as were shown by the length values. An application of the $\chi^{2}$ test for "goodness of fit" gave a value of 3.16 for $\chi^{2}$ and of 0.532 for $P$ (probability that the differences obtained between the frequency distributions of the two forms are due to errors of random sampling), which means that 53 times out of 100 one would expect

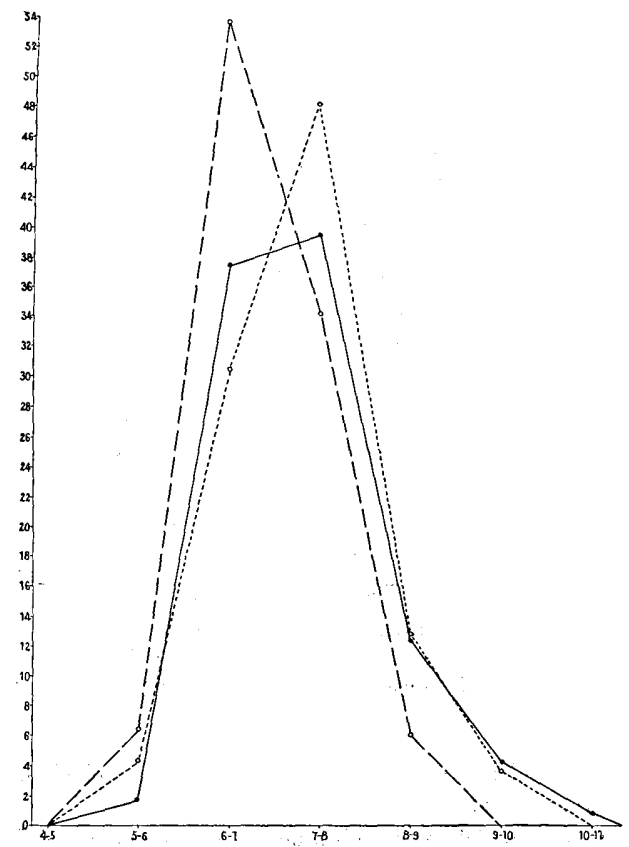

Charp 2. Percentage distribution values for the measurements of breadth of 250 specimens of Giardia muris (dotted line), 250 specimens of Giardia microti (broken line), and 388 specimens of Giardia enterica (solid line). 
as great or greater divergences due to errors of random sampling than are shown in the table. We accordingly conclude that on the basis of breadth the existence of different species cannot be proven in the case of the mouse and the human type, but we would emphasize that

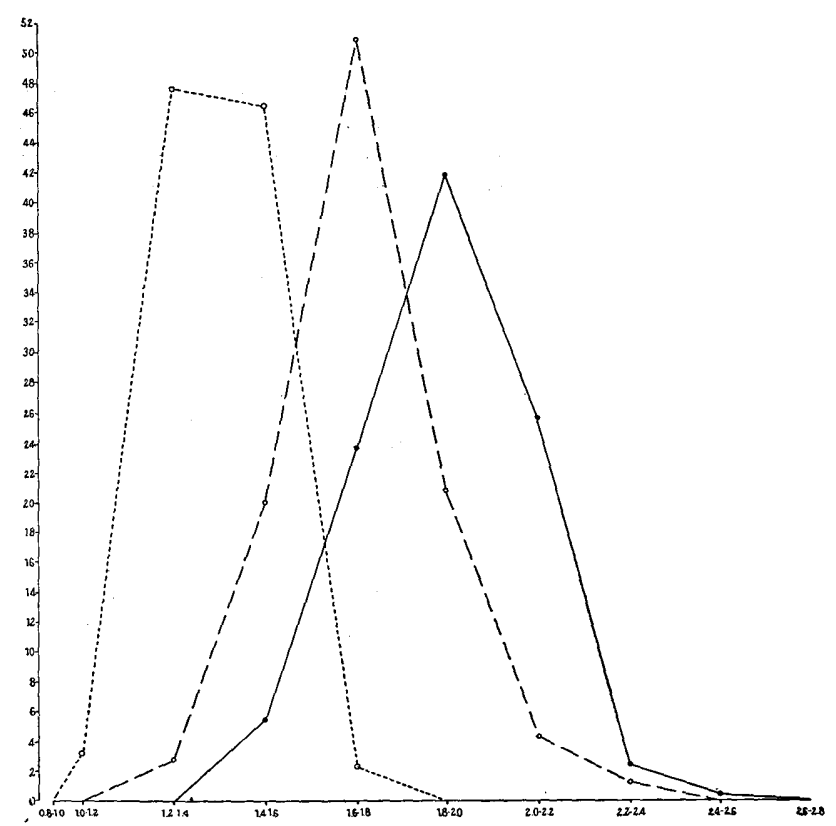

CharT 3. Percentage distribution values for the measurements of length divided by breadth of 250 specimens of Giardia muris (dotted line), 250 specimens of Giardia microti (broken line), and 388 specimens of Giardia enterica (solid line).

this does not mitigate against the conclusions reached on the basis of length that they are different.

The values which were obtained for the rates of length and breadth $(L / B)$ reveal an entirely different size ratio between the human and mouse type and also a somewhat different type of distribu- 
tion. But, inasmuch as the breadth values differ but little, while the length values differ very widely, it is clear that these differences in ratio of length to breadth are merely the expression of the difference in length and need not be discussed further. (Table I and Chart 3 ).

A. comparative study of the cysts of the human and the mouse type.- Our study of the dimensions of the eysts of the two types of organisms under consideration are based upon measurements of 250 specimens of the human type, taken from five different individuals and 100 specimens of the mouse type, taken from two different individuals (both culture rats).

Our results are shown in Table IV and chart 4 . They clearly indicate that the two types can hardly be distinguished, the one from the other, on the basis of size. Considering the smaller length of the mouse trophozoite, as compared with the human form, we had ex-

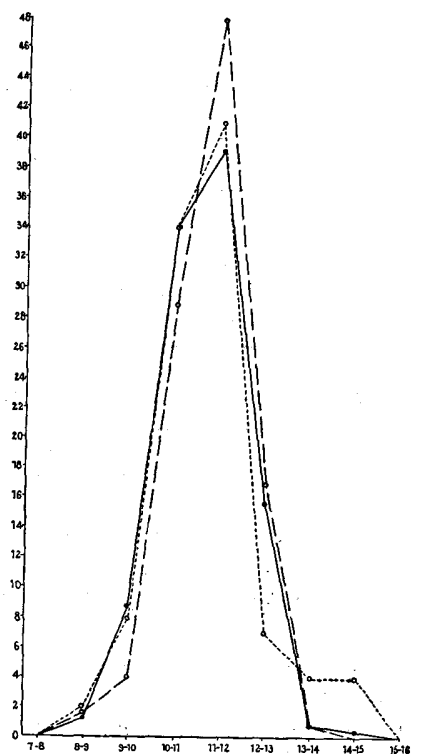

CharT 4. Percentage distribution values for the measurements of length of 100 cysts of Giardia muris (dotted line), 250 eysts of Giardia microti (broken line), and 250 cysts of Giardia enterica (solid line). 
pected to find a corresponding difference in the length of the eysts. But the proportionately greater breadth of the mouse form evidently makes a correspondingly large demand upon space, so that in the end the size of the cysts is nearly the same.

TABLE IV.

Showing the size of 100 specimens of mouse cysts, taken from two different individuals, with their composite values, as compared with the corresponding values obtained from 100 human cysts, also representing two individuals.

\begin{tabular}{|c|c|c|c|c|c|c|c|c|c|}
\hline & \multicolumn{3}{|c|}{ Length. } & \multicolumn{3}{|c|}{ Breadth. } & \multicolumn{3}{|c|}{$\begin{array}{l}\text { Ratio of length } \\
\text { to breadth. }\end{array}$} \\
\hline & 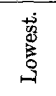 & 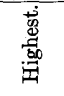 & 㞼 & 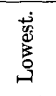 & 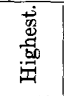 & 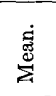 & 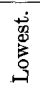 & 络 & 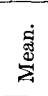 \\
\hline $\begin{array}{l}\text { Mouse Form: } \\
\qquad \begin{array}{l}1 \ldots \ldots \\
2 \ldots \ldots\end{array}\end{array}$ & $\begin{array}{l}8.25 \\
8.25\end{array}$ & $\begin{array}{l}14.25 \\
13.25\end{array}$ & $\begin{array}{l}11.20 \\
10.86\end{array}$ & $\begin{array}{l}6.75 \\
6.25\end{array}$ & $\begin{array}{l}9.25 \\
8.25\end{array}$ & $\begin{array}{l}7.85 \\
7.29\end{array}$ & $\begin{array}{l}1.0 \\
1.1\end{array}$ & $\begin{array}{l}2.1 \\
2.0\end{array}$ & $\begin{array}{l}1.46 \\
1.51\end{array}$ \\
\hline Composite.... & 8.25 & 14.25 & 11.03 & 6.25 & 9.25 & 7.57 & 1.0 & 2.0 & 1.48 \\
\hline $\begin{array}{l}\text { Human Form: } \\
\qquad \text { Md. I . . } \\
\text { Md. III . }\end{array}$ & $\begin{array}{l}8.0 \\
9.0\end{array}$ & $\begin{array}{l}13.0 \\
12.5\end{array}$ & $\begin{array}{l}10.6 \\
11.0\end{array}$ & $\begin{array}{l}6.0 \\
6.5\end{array}$ & $\begin{array}{r}8.5 \\
10.0\end{array}$ & $\begin{array}{l}7.5 \\
8.2\end{array}$ & $\begin{array}{l}1.0 \\
1.1\end{array}$ & $\begin{array}{l}1.8 \\
1.8\end{array}$ & $\begin{array}{l}1.41 \\
1.33\end{array}$ \\
\hline Composite..... & 8.0 & 13.0 & 10.79 & 6.0 & 10.0 & 7.85 & 1.0 & 1.8 & 1.37 \\
\hline $\begin{array}{c}\text { Differences of com- } \\
\text { posites } \ldots \ldots \ldots \ldots\end{array}$ & 0.25 & 1.25 & 0.24 & 0.25 & 0.75 & 0.28 & 0.0 & 0.2 & 0.11 \\
\hline
\end{tabular}

While the two types of eysts can thus not be differentiated from one another on the basis of size they can be readily differentiated morphologically, the essential factor being the appearance of coarse chromidial masses in the cytoplasm of the mouse type, which are either never seen in the human type, or if something suggestive of these masses appears, there is so little of it that it would scarcely attract attention. The multiple loops of the human type which the writer in agreement with Rodenwaldt views as peristomal fibrils are in the mouse type less distinet; if visible at all, appearently single loops only are seen. The longer chromatic rods of the human type which the writer has tentatively viewed as shield border fibrils do not 
seem to occur in the mouse form and parabasal bodies are apparently absent, as in the human type.*

Feeding experiments. - While our morphological findings in the mouse and the human type of Giardia support the idea that the two represent separate species, it oceurred to the writer to test this question also by means of feeding experiments.

Unfortunately it has not been possible to secure human subjects for these experiments. It may be mentioned, however, that one attempt to bring about human infection by starting with mouse material was actually made many years ago, by Moritz and Hölzl (1892). These investigators fed cysts from mice to a human being-a tuberculous patient-but did not succeed in bringing about infection. Their reason for choosing a tuberculous subject was the belief that organisms of this order would be more apt to secure a foothold in a diseased rather than in a healthy subject.

Since human subjects were not available for our purposes it occurred to the writer that the experiment might be reversed and still throw light on the question under diseussion. It seemed reasonable to suppose that if the human form were identical with the mouse form, and differences in size were merely due to differences in environment, then by feeding human cysts to clean hosts of the original type, the mouse form should again appear in these.

Attempts to infect mice with human material have been recorded by several investigators, viz., Perroneito (1888), Bohne and v. Prowazek (1908), Fantham and Porter (1916), Porter (1920), and Deschiens (1921). The purpose of experiments of this order on the

* It should be pointed out in this connection that Kofoid and Christiansen (1915) seem to share the writer's belief that there are no parabasals in the eysts of the-mouse form, for they state (p. 40): "It is also absent in encysted stages (pl. 7, figs. 34-43). Its disappearance (in the vegetative forms?) may therefore be incidental to the process of encystment and be correlated with changing conditions of metabolism." In their recent publication on Giardia enterica (1921), on the other hand, Kofoid and Swezey maintain that parabasals are present in the cysts of this form. They state "the pairs of eurved parabasals are especially prominent" and "the increased size of the deeply staining parabasals . . . in the confinement of the cysts. ...', A study of their illustrations reveals that they view the deeply staining curved fibrils which Rodenwaldt and the writer regard as peristomal fibrils as dividing parabasals. In the part of their paper on Giardia muris, however, in which parabasals were said to be absent, they clearly picture such eurved fibrils (Figs. 35 and 38 ). Evidently their view that parabasals do not oceur in the mouse cysts, or that the fibrils in question in the human cysts are parabasals, is erroneous. In the writer's opinion they are mistaken in viewing the fibrils in the human form as parabasals. 
part of the investigators named was, however, not the same as that of the writer. They were interested in the question of the pathogenicity of giardia, and not in that of the origin of the human infection. Inasmuch as the significance of any results reached by experiments of this order will of course depend upon the question whether the animals fed were clean at the time, and not exposed to infection after being fed until the conclusion of the experiment, any experiments in which this factor was not considered may be eliminated from the discussion. This will probably rule out the results which were obtained by Perroncito, as well as those of Bohne and v. Prowazek, for it was not known at the time when these investigators made their studies that the elimination of giardia eysts, both of human and animal origin, could be intermittent and that the intermissions were often of considerable length (Porter, Dobell, Boeck). It may be mentioned, however, that Perroncito thought that he had succeeded in infecting two white mice out of four, while Bohne and v. Prowazek who fed cysts to rabbits, rats, and young eats and at the same time introduced vegetative forms per anum, obtained negative results only.

Fantham and Porter (1916), on the other hand, state specifically that their animals-kittens and mice-were examined for some time (up to a month) before being fed and that aperients were even used at times to insure that the animals were actually free from a giardia infection. So far as the results from their experiments on mice are concerned (these being the ones that interest us more especially in this connection), it appears that of the nine animals used seven developed the infection and of these four died, while the other two proved resistant. They conclude that mice may serve as reservoirs of infection for human beings.

Very remarkable are the results which Porter obtained in South Africa. This writer states that she found giardias in samples of water "used previously by the parents of native children at the Johannesburg hospital in preparing the food for the infants, identical with those present in the motions of the children." Clean rats whose food was mixed with this contaminated water contracted flagellate diarrhoea and passed large numbers of parasites in the feces.

Deschiens reports experiments on cats and mice. Only the latter concern us at this place. He states that his animals were examined daily for two weeks preceding the feeding experiments. He found that in four animals out of five the ingestion of cysts of the human 
form was followed by a grave or fatal infection in animals which had previously not been parasitized.

My own experiments led to conclusions which are diametrically opposed to those reached by the last three investigators. They were performed on five adult culture rats, and five wild rats. Three of the former had been observed for several weeks in the laboratory and were regarded as clean, while preliminary experiments (by dissection) had shown that our Baltimore city rats are not infected with giardias. The human eysts after being washed by centrifugation with repeated changes of water, until all fecal odor had disappeared, were fed to the animals, partly suspended in their drinking water (inverted bottle arrangement), partly in milk and partly mixed with giardia-free entrails of other rats. Two of the culture rats remained negative for several weeks, so far as the results of fecal examinations went; after this the observations were discontinued. The other animals were killed after intervals varying from seven days to a couple of months and carefully examined for vegetative forms throughout the intestinal tract-all with negative results. It may be mentioned moreover, that none of the animals showed any signs of sickness, viz., diarrhoea.

It might be argued of course that inasmuch as we used culture rats and wild rats the negative results may have been due to our selection of these experimental animals instead of white mice.

To ascertain whether wild rats and culture rats could be infected with the mouse form, the entrails of a white mouse harboring large numbers of giardias of the mouse type were fed to a "clean" white rat. The rat was killed three weeks later and an extensive infection encountered, involving the entire length of the small intestine. The entrails of this animal were then fed to two wild rats. One of these was killed ten days later, the other a month later; both were extensively infected.

We conclude that inasmuch as the mouse form will adapt itself very readily to the intestinal tract of wild rats or culture rats, the human type would likewise have done so, if it were identical with this form.

Since there was evidently no return of the human form to the mouse form in our animals, and after it had been ascertained that two different types of giardias could exist side by side in culture rats, additional feeding experiments with human material were undertaken, using animals which were known to harbor the mouse form, in 
order to determine what became of the ingested cysts. To this end 6 half-grown "hooded" rats were fed freshly passed, well-washed human cysts $(76,400,000)$ suspended in about 10 c.c. of milk, after the animals had had neither food nor drink for about twenty-four hours. In some instances another feeding of an equal quantity was given twenty-four hours later. The animals were killed after intervals varying from two hours and a half to forty-eight hours. Fresh mounts, as well as Schaudinn specimens, were made from the stomach, duodenum, ileum, caecum, and rectum, and carefully examined for eysts and "large" vegetable forms. In the small intestine small mouse type trophozoites only were found, and in the rectum mouse type eysts in the usual small number, showing the characteristie chromidial masses. I would emphasize particularly that the examination made two hours and a half following the administration of such a large dose of cysts revealed a small number only in the stomach which was filled with milk curds. They were evidently dead, however, for they had lost their characteristic refractivity and stained with eosin. No cysts were encountered below the pylorus.

We may conclude that human giardia eysts when fed to culture rats, both young and old, as well as wild rats, both young and old, are destroyed by the gastric juice of these animals. Our feeding experiments thus support the conclusion at which we had arrived on morphological grounds, that human giardiasis is not of rodent origin, so far as the mouse type is concerned; that the mouse type, as well as the human type, constitute separate species. For the former we accept the specific name given by Bensen, viz., Giardia muris. The latter was described in our first paper under the name Giardia enterica, as suggested by Kofoid and Christiansen. This, however, is untenable according to Stiles and should be replaced by the term Giardia lamblia, which also was suggested by Kofoid and Christiansen, though as the result of a misunderstanding of the expression Giardia (s) lamblia used by .Stiles, in a letter to the former. Kofoid apparently overlooked the $s$ and thought that Stiles had actually proposed this name. The name, however, must stand and is perhaps a proper tribute to Lambl who first described and pictured the organism. 


\section{A comparison of the huMan type of Giardia with that} POUND IN THE MEADOW MOUSE.

\section{Probable identity of Kofoid and Christiansen's, Giardia microti and} the form found by Grassi in Arvicola arvalis.

Until Kofoid and Christiansen (1915a) reported the presence of a form of Giardia in the California meadow mouse Microtus californicus californicus (Peale), which they regarded as a new species, "differing in appearance, proportions, and stainability from the widely prevalent Giardia muris, and not possessing the characteristies of any known species of the genus," it had been an open question whether the organism which Grassi found in Arvicola arvalis was identical with the form which the same writer encountered in rats and mice.

During the summer of 1920 I found in the common meadow mouse of Nova Scotia, which was identified as Microtus pennsylvanicus acadicus, a giardia which, excepting for slight differences in size; is apparently identical with that described by Kofoid and Christiansen. Structurally I have been unable to note any essential differences, although here also $I$ eannot follow Kofoid and Christiansen in accepting the existence of a single axostyle.* As in the human form I found a granule located in the center of the interblepharoplastic commissure, which Kofoid and Christiansen do not mention nor picture, but which I was able to demonstrate also in specimens of the California type kindly loaned me by Dr. William C. Boeck.t During the past autumn (1921) I have further encountered the same or a very similar species in the common meadow mouse of Maryland, which indieates sufficiently the probably uniform distribution of this type over the North American continent.

In the same year (1920) that I discovered the occurrence of this type of giardia in the meadow mice of Nova Scotia, there appeared in the Annali d'Igiene an account by Splendore (1920) of the parasites

* But inasmuch as Kofoid acknowledges the existence of two axostyles in his recent paper, dealing with the human type of Giardia, I dare say that he has abandoned his former position in reference to Giardia microti, and would now be willing to concede two axostyles also in this organism.

It is possible that Kofoid and Christiansen, under the influence of their doctrine of the existence of a single axostyle misinterpreted the interblepharoplastie granule as constituting their hypothetical second pair of blepharoplasts, in supposedly dividing forms. So much is certain that forms with four blepharoplasts are rarely seen, and when dividing forms do occur the second pair lie posterior to the original pair and not between the two. 
of "Arvicola" in Italy." The arvicola in question was diagnosed as Pitymys Savii Selys, which, so far as the writer knows, does not occur in North. America, but which, to judge from an accompanying illustration, closely resembles the Mierotinae. Splendore states that this species is very common in southern Italy. Whether it occurs in Lombardy, where Grassi made his initial observations, I do not know, but it would seem likely that this is the animal to which he referred by the name of Arvicola arvalis. In this species Splendore encountered a giardia which he has described under the name Giardia pitymysi, n. sp. Unfortunately Splendore has given no measurements of the organism, merely stating that its size is variable, but he has furnished a good description, accompanied by illustrations (Plate XVI, Figs. 5 and 6) which are sufficiently detailed to make it clear that he was not dealing with the mouse form which we have considered above. So far as one can judge the organism corresponds to Giardia microti. He pictures two axostyles and four basal granules like Wenyon and Bensen, and in addition a fifth granule situated on the arched commissure uniting the central pair of granules, which clearly corresponds to the interblepharoplastic granule of the writer. $t$ Since Splendore shows a rhizoplast conneeting each outer granule with a granule located in the anterior portion of the nuclear membrane, and the latter with the karyosome, he cannot have confused his outer granules with the centrosomes, and I can only conclude that he also, like Bensen and Wenyon, observed forms in which division of the blepharoplasts had already taken place. In two of the three illustrations parabasals are represented and absent in one. They are double, resembling two parallel commas, which obliquely cross the long axis of the animal. The appearance of the parabasals, in association with the elongate form of the organism, elearly separates this type from the mouse type.

The likelihood that the meadow mouse is responsible for the human

* Deschien's (1921) statement that the human type of Giardia was observed in Italy in Mus musculus, $\boldsymbol{M}$. rattus, $\boldsymbol{M}$. decumanus, $\boldsymbol{M}$. sylvestris, in the dog, the eat, the sheep, and the rabbit is incorrect. It is evidently based on Grassi's earlier statement regarding the occurrence of giardias in these asimals, which was made at a time when the question of the existence of species had not yet been raised.

$\dagger I$ note that Kofoid and Swezey interpret this arched commissure as sprouting flagella, but $I$ cannot share this view. I hope to enter into a diseussion of some of their differing interpretations on another oceasion. I have already pointed out that a double commissure exists when a double set of anterior flagella can be seen, set for set. 
infection is, of course, on a priori grounds, even smaller than that the wild mouse or the wild rat represents its source, for bearing in mind that giardiasis is quite common amongst eity dwellers, ehildren especially, it would be difficult to conceive how these could become infected by a rodent which can hardly be regarded as a city dweller itself. Amongst country people, on the other hand, such a possibility would not seem so remote, and if we compare the meadow mouse form with the human form there is certainly a striking resemblance, and one cannot help but feel that even though the two may now constitute different species, some time in the dim distant past man may have acquired his infection from this source. But the problem before us is to decide whether the two forms are identical at the present time, or whether they represent separate species.

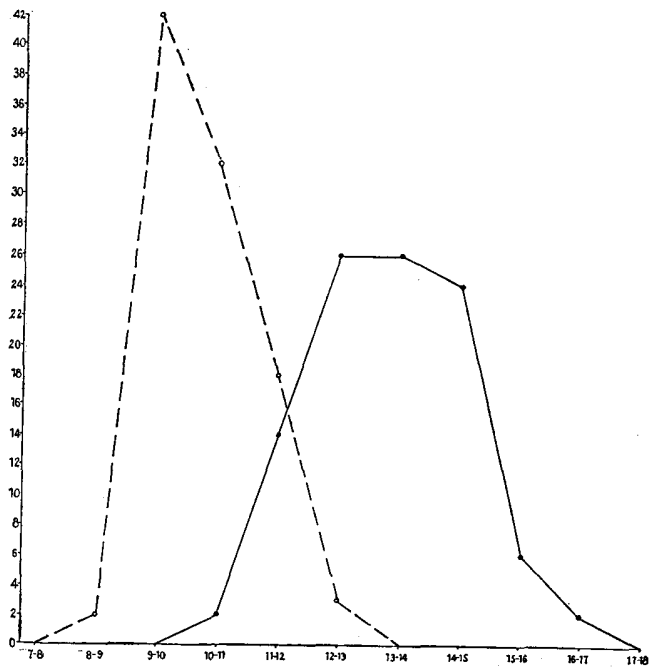

Chart 5. Percentage distribution values for the measurements of length of 50 specimens of Giardia muris (broken line) and 50 specimens of Giardia sp. (solid line).

So far as the general morphology of the two forms is concerned no essential points of difference seem to exist excepting in the form of the parabasals and the size of the trophozoites (Text figures 1 and 
2). As in the human form and the mouse form the parabasals are frequently absent and I do not hesitate to say that where this is the case it is impossible to differentiate between the two, excepting on the basis of size (see below).

In their paper on the meadow mouse form Kofoid and Christiansen state that there is a "marked difference in the parabasals, which are slender and curved in $G$. microti, but much larger and massive and apparently fused in one body; according to Bensen (1908), in the human form." In referring to Rodenwadlt's figures, however, they find that these leave "little doubt that there are, at times, at least, two stout brush-shaped parabasals in an obliquely curved position (in the human form) ...." "These are very much like those of $G$. microti except that they are a little stonter."

My own observations accord with those of Kofoid and Christiansen that in the meadow mouse form two parabasals can often be distinguished, when present at all. Kofoid and Swezey (1922) state that in the human form also there are two parabasals, and they point out that I have erroneously represented the parabasals as single, in my drawing of the human form in Hegner and Cort's Diagnosis (1921).

In my detailed description of the human form (1921) I stated that the parabasal body usually presents a club-shaped or a heavy comma-like appearance, and that occasionally one gets the impression as though the structure were split longitudinally. If Kofoid and Swezey were correct in their statement that "typically" the parabasals appear as a pair of comma-shaped structures it should be unnecessary to add that "failure to focus out and analyze the pair of parallel parabasals underlies the interpretation... of these organs as a single rather than a paired structure" and that they "find it possible to analyze the seemingly single bodies into the pair ....."

In my experience, the double or split appearance in the human form is the exception and not the rule, and this fact constitutes an actual point of difference between the two forms. Other investigators evidently share this view.

* In this connection I would point out that Boeck (1917), one of Kofoid's pupils, makes the following statement (p. 8) in reference to the parabasals of Giardia microti: "The parabasal bodies composed of one broad or two narrow bands ... which in some cases appear fused in one body. . . It plays no part in mitotic activity." In his plate of Figures 1, 2, 3, 4, 9. and 11 he represents it as single. 
In their brief discussion of the "specific differences" between the human form and Giardia from rodents, which is embodied in their paper on Mitosis and Fission in Giardia enterica (1922) Kofoid and

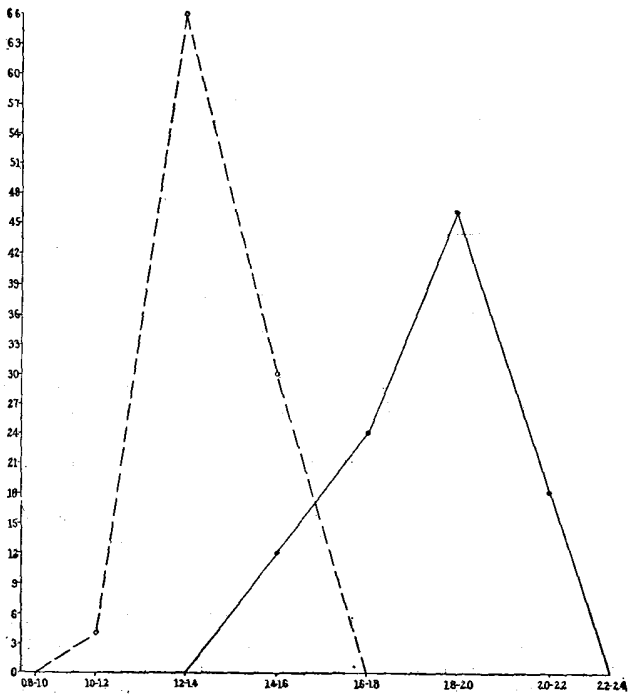

CharT 6. Percentage distribution values for the measurements of length divided by breadth of 50 specimens of Giardia muris (broken line) and 50 speeimens of Giardia sp. (solid line).

Swezey refer to the shape of the blepharoplasts and state that in the human form the head of the axostyle is not expanded by them, while in the meadow mouse form it is expanded. Inasmuch as Kofoid has not yet formally abrogated his elaim to a single axostyle in the latter form, but accepts two axostyles for the human form, this is somewhat confusing. I have already emphasized that no differences exist between the two forms in this respect.

Kofoid and Swezey further suggest that in the meadow mouse form there is an antero-lateral and a posterior basal granule while in the human form these are absent. In my experienee, based upon the examination of many hundreds of specimens, these granules were 
TABLE V.

Measurements which were obtained in the study of the body of the trophozoite from five different cases of Giardia microti infection (Nova Scotia type), together with the corresponding composite values, as compared with the figures which were obtained from five different cases of Giardia enterica infection and their corresponding composite values.

\begin{tabular}{|c|c|c|c|c|c|c|c|c|c|c|}
\hline & \multirow{2}{*}{ 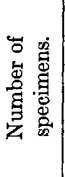 } & \multicolumn{3}{|c|}{$\begin{array}{l}\text { Length of } \\
\text { body. }\end{array}$} & \multicolumn{3}{|c|}{$\begin{array}{l}\text { Breadth of } \\
\text { body. }\end{array}$} & \multicolumn{3}{|c|}{$\begin{array}{c}\text { Ratio of body } \\
\text { length to breadth. }\end{array}$} \\
\hline & & 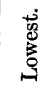 & 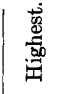 & 离 & 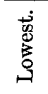 & 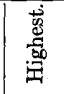 & 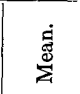 & 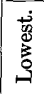 & 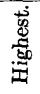 & 焉 \\
\hline Meadow mouse & & & & & & & & & & \\
\hline 16 & 50 & 9.25 & 13.25 & 11.18 & 5.75 & 8.25 & 7.09 & 1.3 & 2.0 & 1.61 \\
\hline 13 & 50 & 9.95 & 12.75 & 11.10 & 5.75 & 8.25 & 7.01 & 1.3 & 2.0 & 1.62 \\
\hline 12 & 50 & 9.25 & 12.75 & 11.01 & 5.25 & 8.75 & 6.66 & 1.3 & 2.2 & 1.68 \\
\hline 2 & 50 & 9.25 & 13.25 & 10.71 & 5.25 & 7.25 & 6.33 & 1.3 & 2.2 & 1.74 \\
\hline 22 & 50 & 9.25 & 13.25 & 11.25 & 5.25 & 7.75 & 6.86 & 1.4 & 1.9 & 1.65 \\
\hline Composite $\ddagger$ & 250 & 9.25 & 13.25 & $\begin{array}{r}11.06 \\
\pm 0.04\end{array}$ & 5.25 & 8.75 & $\begin{array}{r}6.79 \\
\pm 0.03\end{array}$ & 1.3 & 2.2 & $\begin{array}{c}1.66 \\
\pm 0.008\end{array}$ \\
\hline Maryland I. .... & 65 & 10.25 & 20.25 & 14.11 & 6.25 & 10.25 & 7.87 & 1.4 & 2.2 & 1.80 \\
\hline Maryland II.... & 82 & 11.25 & 17.25 & 14.34 & 6.25 & 9.25 & $\cdot 7.83$ & 1.5 & 2.3 & 1.80 \\
\hline Maryland III... & 50 & 9.25 & 15.25 & 11.61 & 5.00 & 8.00 & 6.31 & 1.5 & 2.0 & 1.79 \\
\hline South Carolina. & 73 & 10.25 & 15.25 & 12.70 & 5.75 & 8.75 & 6.94 & 1.4 & 2.2 & 1.80 \\
\hline French....... & 118 & 11.25 & 17.75 & 14.28 & 6.75 & 10.25 & 7.82 & 1.4 & 2.3 & 1.60 \\
\hline Composite* . & 388 & 9.25 & 20.25 & $\begin{array}{l}13.70 \\
\pm 0.2\end{array}$ & 5.00 & 10.25 & $\begin{aligned} & 7.46 \\
\pm & 0.034\end{aligned}$ & 1.4 & 2.3 & $\begin{array}{c}1.84 \\
\pm 0.009\end{array}$ \\
\hline $\begin{array}{l}\text { Difference be- } \\
\text { tween the two }\end{array}$ & & 0.00 & 7.00 & 2.64 & 0.25 & 1.50 & 0.67 & 0.1 & 0.1 & 0.18 \\
\hline
\end{tabular}

as frequently found to be present in the human form as in the animal forms, and as frequently absent in the animal forms (both rats, mice, and meadow mice) as in the former. Their presence or absence certainly does not constitute a specific difference. Like Kofoid and his

* The composite means were obtained, not from the means of the five animals, but from the measurements of the total number. 
collaborators, I have found no basal granule at the points of exit of the postero-lateral flagella in any form.

As regards general differences in form my findings agree with those of Kofoid and Swezey, viz., that the human form tends to a eoneave outline along the lateral contour of the tail, while the meadow mouse form is more nearly straight, though this difference is not pronounced in many specimens.

The most important difference between the two forms is that of size and on size alone in my opinion the two forms can be differentiated, providing that a sufficiently large number of specimens be examined. My findings in regard to variations in size are given in Table $\mathrm{V}$ and charts 1,2 and 3.

It will be noted that there is not only a material difference in mean length, but also an entirely different type of distribution. The differences in mean breadth are not so marked, but there is a considerable dissimilarity in distribution here also, which is further brought out by the $x^{2}$ test.

The value for $\chi^{2}$ was found to be 11.5471 and for $P, 0.0009$, which means that only 9 times in 1,000 would we expect as great or greater divergences due to errors of random sampling. While this divergence is much more striking than that between $G$. muris and Giardia enterica to much stress should not be layed upon this difference.

TABLE VI.

A comparison of the measurements, in micra, of 250 oysts of Giardia microti (composite material from a colony of 20 animals) with 250 cysts of Giardia enterica (composite values from 5 cases).

\begin{tabular}{|c|c|c|c|c|c|c|c|c|c|c|}
\hline & & \multicolumn{3}{|c|}{ Length. } & \multicolumn{3}{|c|}{ Breadth. } & \multicolumn{3}{|c|}{$\begin{array}{l}\text { Ratio of length } \\
\text { to breadth. }\end{array}$} \\
\hline & & 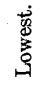 & $\begin{array}{l}\text { 它 } \\
\text { 总 } \\
\text { 焉 }\end{array}$ & 胥 & 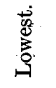 & 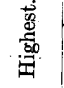 & 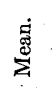 & 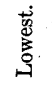 & $\frac{\text { 㺃. }}{\frac{30}{30}}$ & 总 \\
\hline $\begin{array}{l}\text { Meadow } \\
\text { mouse form }\end{array}$ & 250 & 8.25 & 13.75 & 11.11 & 5.25 & 10.25 & 7.58 & 1.1 & 1.9 & 1.49 \\
\hline Human form. & 250 & 8.00 & 14.00 & 10.70 & 6.00 & 10.00 & 7.47 & 1.0 & 2.0 & 1.37 \\
\hline Difference... & & 0.25 & 0.25 & 0.41 & 0.75 & 0.25 & 0.11 & 0.0 & 0.1 & 0.12 \\
\hline
\end{tabular}

The differences in the ratio between length and breadth between the two forms are equally striking. 
A comparison of the cysts of Giardia enterica with those of Giardia microti.-In this connection I would briefly point out that, while no essential points of difference exist in the size of the cysts of the meadow mouse form, as compared with the human form (see Table VI and chart 4), it is noteworthy that the eysts which appear in the feces of man never show any evidence of plasmotomy and have for the most part not progressed beyond the quadrinucleate stage, with the retention of the second pair of nuclei close to the first pair. A large percentage of the meadow mouse cysts, on the other hand; as they appear in the feces, contain two perfectly formed individuals. This alone would serve to differentiate the two forms.

Feeding experiments.-In conclusion I would refer to a number of experiments in which the attempt was made to infect wild rats, culture rats, and wild mice with the meadow mouse giardia: In all but one of these experiments the entire entrails of freshly killed, naturally infected meadow mice were fed to wild rats and culture rats. The animals were killed after a number of days and the intestinal contents from various sections examined for the presence of giardias of the meadow mouse type. The results were always entirely negative. In the one exceptional instance, four young house mice, just able to eat alone, were taken from a nest (in the seat of an old automobile) and placed in a large eage, containing twenty naturally infected meadow mice, where they lived together, under ground (sod), for three months. A fifth mouse of the same litter was killed and examined for protozoa with a negative result. During the three months the young mice were never seen to feed in the day time, when the meadow mice invariably appeared, and were obliged to drink heavily cyst-infected water, which was left by the latter, during a period of almost six weeks, while the animals were fed no fresh vegetables. The earth was heavily infected and the mice thus freely exposed. At the expiration of the three months but one of the house mice could be examined (the rest escaped), and although a careful search was made throughout the intestinal tract no giardias of any kind were found, whereas nearly 100 per cent. of my meadow mouse material was found infected. Evidently, it is just as impossible to infect house mice with the giardia of meadow mice as it was found impossible to infect. wild rats and culture rats with the human form. 
SUMmary.

1. On the basis of our morphological, biometrical and experimental studies we believe to have established that specifie differences exist between the human giardia and the mouse form, as was first suggested by Bensen and subsequently by Kofoid and Christiansen, and that similar differences also exist between the human form and the meadow mouse form and between the latter and the mouse form, as was first suggested by Kofoid and Christiansen, though in both instances on what we regard as insufficient evidence.

2. It seems warrantable to assign species names to the three forms, and we accept that of muris for the mouse form, as suggested by Bensen, and the name microti for the meadow mouse form, as suggested by Kofoid and Christiansen. For the human form we believe that Stiles, as set forth above, is justified in rejecting Kofoid's term enterica and that according to the rules of nomenclature the organism should henceforth be known as Giardia lamblia.

3. Culture rats and wild rats cannot be infected with Giardia lamblia, while they may readily be infected with Giardia muris.

4. Culture rats, wild rats, and wild mice cannot be infected with Giardia microti.

5. There is no basis for the assumption that the human infection is referable to either rats, mice, or meadow mice.

6 . We believe that the human infection is of human origin.

BENSEN, W.

BIBLIOGRAPHY.

1908. Bau u. Arten d. Gattung Lamblia. Zeitsch. f. Hygiene u. InfekBoEcK, W. C. tionsk., LXI, 109-114.

1917. Mitosis in Giardia microti. Univ, Calif. Publ. Zool, XVIII, I. 1919. Studies on Giardia microti. Ibid., XIX, 116.

Bohne, A. and v. Prowazek, S.

1908. Zur Frage d. Flagellatendysenterie. Areh. f. Protistk., XII, 1-8. Deschiens, R.

1921. Les entérites à Giardia (Lamblia). T'ravail Lab. Parasit. Faculté de Med. Paris. Imprimerie Jehlen.

DoBeLL, C. AND Low, G. C.

1916. A note on the treatment of lamblia infections. Lancet, XCIV, 2, 1053.

Fantham, H. B. and Porter, A.

1916. The pathogenicity of Giardia intestinalis to men and experimental animals. Brit. Med. Journ., II, 139-141. 
Grasst, B.

1881. Di un nuovo parassita dell'uomo, Megastoma entericum. Gaz. đ. Ospidali, II, 577-580.

HEGNER, R. W. AND CORT, W. W.

1921. Diagnosis of Protozoa and Worms Parasitic in Man. Baltimore, Md., Williams and Wilkins.

Kofold, C. A. and Christiansen, E. B.

1915a. On Giardia microti, sp. nov., from the meadow mouse. Univ, Calif. Publ. Zool., XVI, 23-29.

1915b. On binary and multiple fission in Giardia muris (Grassi). Ibid., XVI, 30-54.

Koford, C. A. AND Swezex, O.

1922. Mitosis and fission in the active and encysted phases of Giardia enterica (Grassi) of man, ete. Ibid., XX, 199-234.

MORITZ, F. AND HöLZL, H.

1892. Ueber Häufigkeit und Bedeutung d. Vorkommens von Megastoma entericum im Darmkanal d. Menschen, Münch, med. Woch.,

Noc, F. XXXIX, 831-835.

1890. Observations sur le cycle évolutif de Lamblia intestinalis. Bull. Soe. Path. Exot., II, 93-97.

Perroncito, E. Cited by Piceardi, G.

1895. Sur quelques protozoaires des selles de l'homme. Progrès med., XXIII, 377.

Porter, A.

1916. An enumerative study of the eysts of Giardia intestinatis in human dysenteric feces. Lancet, XCIV, I, 1166.

1919. A survey of the intestinal entozoa ... observed among natives in Johannesburg. Memoirs of the South African Institute of Medical Research, No. 11, 39.

SIMYON, C. E.

1921. Giardia enterica: A parasitic intestinal flagellate of man. Am. SPLENDORE, A. Journ. Hyg., I, 440-482.

1920. Sui parassiti delle Arvicole. Annali d'Jgiene, XXX, Reprint. WENYON, C. M.

1907. Observations on the protozoa in the intestine of mice. Arch. $f$. Protistenk. Suppl., I, 190-193.

\section{EXPLANATION OF PLATE XVI.}

FIG. 1. Reproduction of Wenyon's representation of the giardia found by him in eulture mice (1907).

Fig. 2. Reproduction of Bensen's figure of Giardia (lamblia) muris (1908).

FIG. 3. Reproduction of Kofoid and Christiansen's representation of Giardia muris (Pl. 5, Fig. 1) with quieseent nueleus (1915).

FIG. 4. Reproduction of Boeck's representation of Giardia microti in resting stage (Pl. 1, Fig. 1, 1917).

FIGS. 5 and 6. Representations of Splendore's Figs. 3 and 4 (Pl. 7) of Giardia pitymysi (1920). 
PLATE XVI.

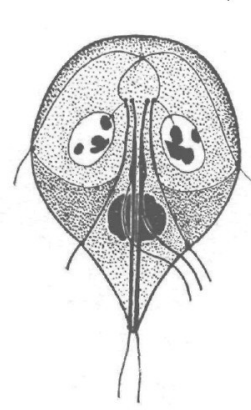

FIG, 2.

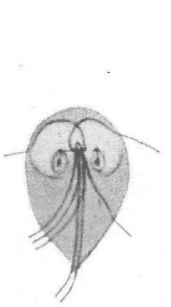

FIG. 5.

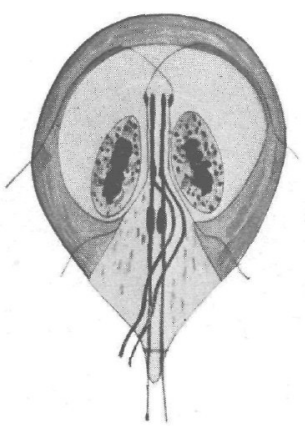

Fig. 1.

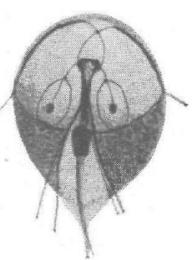

Fig. 3.

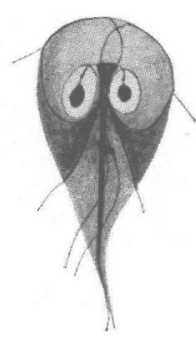

Fig. 4.

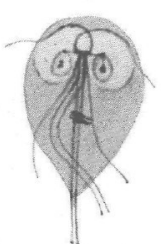

FIG. 6. 